\title{
Effect of Prior Information of the Number of Sets on Training Volume in Women
}

\author{
Efeito da Informação Prévia do Número de Séries Sobre o Volume de Treino em Mulheres
}

\author{
Luiz Fabiano Vilela de Almeida ; Alex Silva Ribeiro*a \\ ${ }^{a}$ Unopar, Stricto Sensu Program in Physical Exercise in Health Promotion. PR, Brazil. \\ *E-mail: alex-silvaribeiro@hotmail.com,
}

\begin{abstract}
The induced adaptations from resistance training are dependent on the adequate manipulation of the variables involved in training, and volume is one of the most important. However, high volume training can be more stressful, thus prior information of the training volume to be performed may affect performance. The aim of this study is to verify the influence of prior knowledge of the number of sets to be performed on the training volume. For this, ten women ( $44 \pm 2$ years, $66 \pm 9 \mathrm{~kg}, 165 \pm 3 \mathrm{~cm}, 24 \pm 2 \mathrm{~kg} / \mathrm{m} 2)$ with previous experience in resistance training ( $\geq 6$ months) performed six sets in $45^{\circ}$ leg press exercise in three conditions,: in the first (C1) the participants were informed that they would perform six sets and they completed them. In the second condition (C2), they were told they would perform three sets, however, after executing the third set, they were told to complete three more sets. In the third (C3), they did not receive information about how many sets they would complete, but they also did six sets. All sets were performed until the momentary concentric failure at $70 \%$ of the one repetition maximum. It was noted that there was no statistically significant difference among the conditions for the total number of repetitions $(\mathrm{C} 1=119 \pm 44 ; \mathrm{C} 2=$ $123 \pm 47 ; \mathrm{C} 3=121 \pm 47 ; \mathrm{P}=0.98$ ). Therefore, the results suggest that prior information on the number of sets to be performed in the session does not affect the volume of repetitions performed by middle-aged women.
\end{abstract}

Keywords: Exercise. Physical Education and Training. Aging.

\section{Resumo}

As adaptações induzidas pelo treinamento resistido são dependentes da adequada manipulação das variáveis envolvidas no treinamento, sendo o volume uma das de maior destaque. Porém, um treinamento com alto volume pode ser mais desgastante, logo, a informação prévia do volume de treino a ser realizado poderá afetar o desempenho. O objetivo deste estudo foi verificar a influência do conhecimento prévio do número de séries a serem executadas sobre o volume de treino. Para isso, 10 mulheres (44 2 anos, $66 \pm 9 \mathrm{~kg}, 165 \pm 3 \mathrm{~cm}, 24 \pm 2 \mathrm{~kg} / \mathrm{m}^{2}$ ) com experiência prévia em treinamento resistido ( $\geq 6$ meses) realizaram seis séries no exercício leg press $45^{\circ}$ em três condições distintas, a saber: na primeira condição (C1) as participantes foram informadas que realizariam seis séries e as completaram. Na segunda condição (C2), foram comunicadas que fariam três séries, porém, após executar a terceira série, elas foram orientadas a completar mais três séries. Já na terceira condição (C3), não receberam informação sobre quantas séries cumpririam, mas também fizeram seis séries. Todas as séries foram realizadas até a falha momentânea concêntrica a $70 \%$ da força máxima, determinada mediante teste de uma repetição máxima. Notou-se que não houve diferença estatisticamente significante entre as condições para a quantidade total de repetições $(C 1=119 \pm 44 ; C 2=123 \pm 47 ; C 3=121 \pm$ 47; $P=0$,98). Portanto, os resultados sugerem que a informação prévia da quantidade de séries a serem executadas na sessão não afeta o volume de repetições praticadas por mulheres de meia idade.

Palavras-chave: Exercício Físico. Educação Física e Treinamento. Envelhecimento.

\section{Introduction}

Natural aging process is accompanied by a series of negative changes for the organism, with the reduction of strength and muscle mass characteristic of this process ${ }^{1,2}$, which are associated with general health, autonomy and survival of elderly people ${ }^{3,4}$. Although the progressive decline in muscle strength occurs in both sexes, women present lower levels of muscle strength and mass, as compared to men, during the different adult life cycles ${ }^{5,6}$. In this sense, regular exercise practice has been encouraged to attenuate or reverse these deleterious processes associated with aging ${ }^{7,8}$.

Among the different physical exercise modalities, resistance training can promote important improvements in strength, muscle mass and functionality levels ${ }^{9-11}$. However, the benefits related to the practice of resistance training are dependent on the proper manipulation of the variables that make up the prescription of a training program, including the load used, the number of series and repetitions, the recovery interval between series and exercises, the weekly frequency, among others ${ }^{12,13}$.

In the midst of these variables, training volume plays an important role in providing hypertrophy and increased muscle strength ${ }^{14-16}$. However, a higher training volume will also lead to greater physical effort ${ }^{17}$. Therefore, the knowledge of the final moment of exercise may induce different responses, since there is the possibility that the anticipation of information 
on the number of series will affect the total volume of a given exercise, so that when the practitioner believes that he or she will perform low volume, he or she may, even if unconsciously, have better performance and carry out more repetitions. Thus, Billaut et al. ${ }^{18}$ observed that the previous knowledge of training volume affects the performance of sprints performed on a cycle ergometer in women athletes. However, this information needs to be confirmed in other motor tasks and, in particular, in resistance exercises.

Therefore, as it is not well established in the literature if the number of series to be performed impacts the volume of a given exercise, the objective of this study was to analyze the influence of the previous knowledge of the number of series to be observed on the number of repetitions performed. The hypothesis of the study is that the anticipation of information about how many series would be performed could affect the training volume, in which knowledge about the lowest volume would induce a better performance in the initial series. This hypothesis was based on the assumption that, even unconsciously, there would be a tendency to save effort in the higher volume condition, thus leading to lower energy expenditure and greater fatigue during the first series.

\section{Material and Methods}

\subsection{Participants}

Ten women with previous experience ( $\geq 6$ months) in resistance exercises were selected for convenience to participate in this experiment. All of them completed a questionnaire to verify the health history and only those who met the following criteria were included in the study: not presenting a history of metabolic or musculoskeletal dysfunctions that prevented the exercise and having a minimum experience of six months with resistance exercises. As an exclusion criterion, they could not have eaten beverages and/or food containing caffeine during the 24 hours prior to the application of the tests.

After being informed on the purpose and procedures of the study, all the selected participants signed a Written Informed Consent, highlighting that this study was submitted for analysis and approved by the Ethics Committee in Research by Universidade Norte do Paraná, according to the standards of Resolution n. ${ }^{\circ}$ 466/2012, the Health National Council, on the research involving human beings (Opinion n. ${ }^{\circ}$ 3.018.806).

\subsection{Experimental design}

The participants carried out a total of four visits to the physical exercise center in alternate days, separated by a minimum interval of $48 \mathrm{~h}$. Anthropometric measurements, individual interviews and one maximal repetition (1RM) were performed at the first visit. From this point on, a randomized design (random.org), balanced and cross-over was used for the analysis of the three experimental conditions, namely: in one session, the participants were informed that they would perform six series and completed them. In the second condition (C2), they were told they would perform three sets, however, after executing the third set, they were told to complete three more sets. For another condition, they did not receive information about how many series would be performed, however, they also completed six series. Therefore, the number of series was similar among the conditions, differing only on the previous information of the number of series that would be performed. The experimental design of the study is shown in Figure 1.

Figure 1 - Experimental design of the study

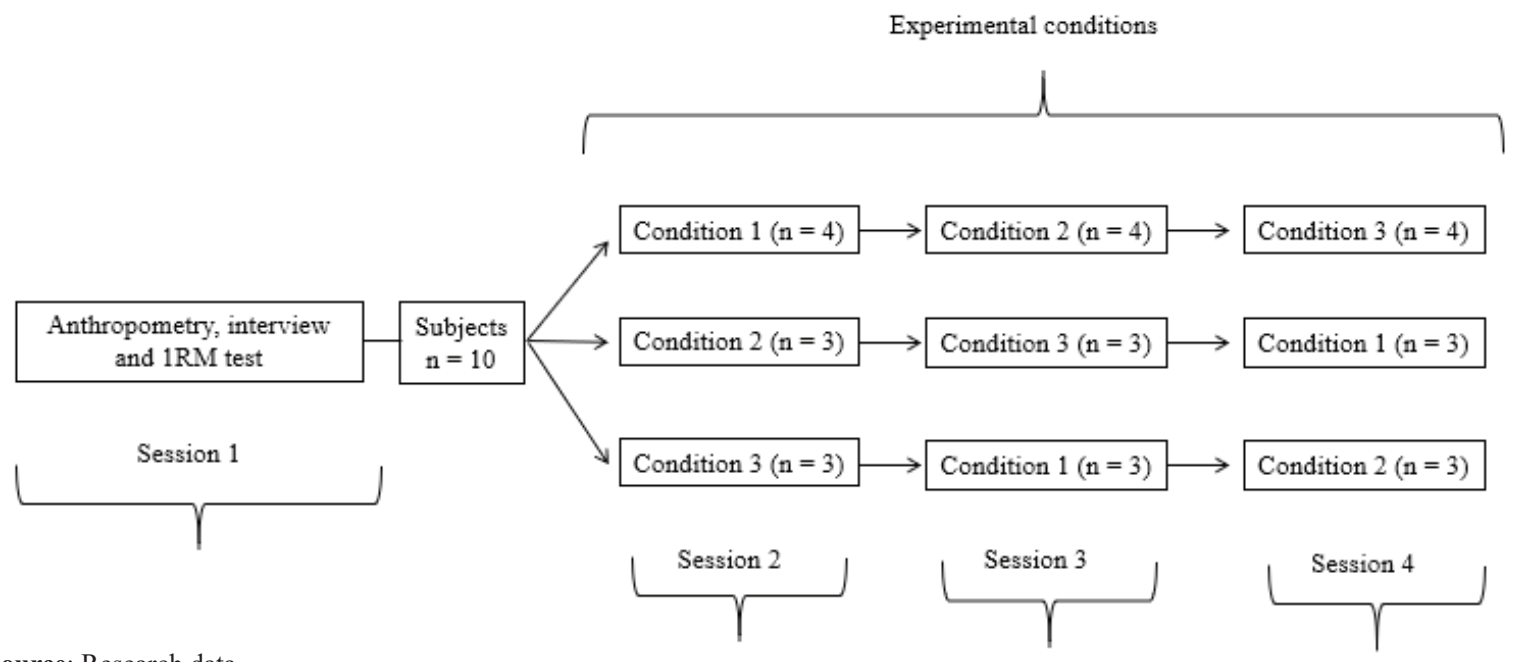

Source: Research data.

\subsection{Anthropometry}

Body mass was measured on a digital reading scale (Balmak, Class III model, São Paulo, SP, Brazil), with a scale of $0.1 \mathrm{~kg}$, while height was determined by means of a stadiometer attached to it, with a scale of $0.1 \mathrm{~cm}$, with INMETRO seal. Based on these measurements, the body mass index was calculated by the ratio between body mass and height square. 


\subsection{Maximum force test}

One maximal repetition (1RM) was used to determine the maximum strength in the leg press $45^{\circ}$ exercise. The participants were previously instructed on all the procedures and techniques required in the test, and a previous warm-up was performed before the first attempt, in the exercise itself, with a series from six to 10 repetitions, with approximately $50 \%$ of the load to which they would be tested initially. From this, a two minute interval was allowed and then the first attempt was initiated.

For each attempt, the participants were encouraged to make two repetitions. In case at least one repetition was performed, the load was increased and a next attempt was performed. In case there was no repetition, the load was reduced and a new attempt was performed. In total, the participants had three attempts, with a three to five minute interval between them. The load recorded as 1RM was the one in which each managed to perform a single maximum repetition ${ }^{19}$. It is worth pointing out that the execution form and technique of each exercise were standardized and continuously monitored in an attempt to ensure the test efficiency.

\subsection{Experimental conditions}

The participants performed in all experimental conditions the exercise leg press 45 to $70 \%$ of 1RM. This exercise was selected because it was widely disseminated in resistance exercise centers, is easy to perform, has efficiency for strengthening and hypertrophy of lower limb muscles, especially quadriceps and gluteus maximus ${ }^{20}$, besides being safe, when performed with compatible load and adequate technique $^{21}$. For performing the exercise, the participants were left with the back and hip supported on the equipment, holding the lateral straps. The feet positioning was slightly more distant than the hip width, and the tip of the feet was pointing outwards, at an opening of approximately 35 to 45 degrees. During movement, the patella remained aligned with the tip of the feet, without performing the dynamic knee valgus. Eccentric muscle action was standardized with approximately 90 degrees of knee flexion.

In addition, the participants were oriented to perform as many repetitions as possible, maintaining the cadence and the predetermined technique. They were also instructed to avoid rest in the transition phases between repetitions (end of concentric muscle action and beginning of eccentric phase). The speed of movement was in the ratio of 1: $2 \mathrm{~s}$ for the concentric and eccentric phases respectively. A rest period of $120 \mathrm{~s}$ was offered among the series. The series were performed until the voluntary failure or the inability to perform the exercise with the appropriate technique. Verbal encouragement was offered in all conditions to the participants, who were informed to abstain from beverages and food containing caffeine 48 hours before the sessions, held at the same time of day to avoid possible effects of the circadian cycle.

\subsection{Statistical Analysis}

Shapiro-wilk test was used to analyze the data distribution analysis. Homogeneity of variances was confirmed by the Levene test; Analysis of Variance (ANOVA) was applied for repeated measurements for comparison between conditions and series. Whereas the Mauchly test was used to verify the roundness; in case of violation of this assumption, the analyzes were adjusted by greenhouse-Geiser correction. Bonferroni's post hoc test for multiple comparisons was adopted to identify the specific differences between the series. One -way ANOVA compared the total number of repetitions and the total load volume. It is worth noting that, for all the statistical analyzes, $a$ significance of $P<0.05$ was accepted. The data were processed at STATISTICAL Program, version 10.0.

\section{Results and Discussion}

The information regarding the general characteristics of the participants is presented in Table 1. The maximum number of repetitions performed in each series, according to the condition, is shown in Table 2. For all the conditions there was a reduction in the number of repetitions from the first to the second series $(P<0.05)$. In $\mathrm{C} 2$ and $\mathrm{C} 3$, there was a reduction in the number of repetitions from the second to the third series, however, this reduction was not observed in $\mathrm{C} 1(P>0.05)$. For all the conditions, there was no difference between the third and fourth series $(P>0.05)$, indicating stabilization. However, there was a difference between the five and six series for the second series, and the sixth series for the third series $(P<0.05)$.

Table 1 - General characteristics of the sample $(n=10)$

\begin{tabular}{|l|c|c|c|c|}
\hline & Average & $\begin{array}{c}\text { Standard } \\
\text { Deviation }\end{array}$ & Minimum & Maximum \\
\hline Age (years) & 44.7 & 2.3 & 42 & 50 \\
\hline $\begin{array}{l}\text { Body mass } \\
\text { (kg) }\end{array}$ & 66.9 & 9.8 & 46 & 84 \\
\hline Height (cm) & 165.9 & 3.6 & 159 & 172 \\
\hline BMI (Kg/m $\mathbf{2})$ & 24.2 & 2.8 & 18 & 28 \\
\hline
\end{tabular}

Note. BMI= body mass index.

Source: Research data.

Table 2 - Number of repetitions according to the experimental condition $(\mathrm{n}=10)$

\begin{tabular}{|l|c|c|c|}
\hline & C1 & C2 & C3 \\
\hline Series 1 & $26.3 \pm 6.9$ & $28.2 \pm 8.4$ & $27.8 \pm 9.1$ \\
\hline Series 2 & $21.6 \pm 7.1^{\mathrm{a}}$ & $23.2 \pm 8.4^{\mathrm{a}}$ & $22.3 \pm 8.3^{\mathrm{a}}$ \\
\hline Series 3 & $19.4 \pm 7.2^{\mathrm{a}}$ & $19.9 \pm 7.7^{\mathrm{ab}}$ & $19.5 \pm 7.7^{\mathrm{ab}}$ \\
\hline Series 4 & $18.5 \pm 7.5^{\mathrm{ab}}$ & $18.2 \pm 7.6^{\mathrm{ab}}$ & $18.4 \pm 7.8^{\mathrm{ab}}$ \\
\hline Series 5 & $17.6 \pm 7.7^{\mathrm{ab}}$ & $17.9 \pm 7.9^{\mathrm{ab}}$ & $17.7 \pm 7.7^{\mathrm{ab}}$ \\
\hline Series 6 & $16.5 \pm 8.1^{\mathrm{abc}}$ & $16.2 \pm 7.9^{\mathrm{abc}}$ & $15.9 \pm 7.6^{\mathrm{abc}}$ \\
\hline
\end{tabular}

Note: ${ }^{\mathrm{a}} P<0.05$ vs. series $1 .{ }^{\mathrm{b}} P<0.05$ vs. series $2 .{ }^{\mathrm{c}} P<0.05$ vs. Series 3 . Values expressed in mean and standard deviation.

Source: Research data.

Table 3 shows the total number of repetitions performed in the six series and the total load volume depending on 
the condition. It is observed that there was no statistically significant difference among the conditions $(P>0.05)$.

Table 3 - Total number of repetitions and load volume according to the experimental condition $(n=10)$

\begin{tabular}{|l|c|c|c|c|}
\hline & C1 & C2 & C3 & $\boldsymbol{P}$ \\
\hline Repetitions & $119 \pm 44$ & $123 \pm 47$ & $121 \pm 47$ & 0.98 \\
\hline $\begin{array}{l}\text { Load } \\
\text { volume (kg) }\end{array}$ & $20155 \pm$ & $20797 \pm$ & $20459 \pm$ & 0.98 \\
\hline
\end{tabular}

Note: Load volume $=$ repetitions $\mathrm{x}$ load. Values expressed in mean and standard deviation.

Source: authors' information.

The main finding of the present study was that prior knowledge of the number of series to be performed on leg press $45^{\circ}$ did not affect the total volume of exercise. The initial hypothesis that the anticipation of information about the number of series to be performed would affect the volume of training was not confirmed in the present experiment. Although the mean values indicate a greater number of repetitions in the first series for $\mathrm{C} 2$ compared to $\mathrm{C} 1$, this difference was not statistically significant.

Moreover, it would be expected that the best performance in the initial series reflected in worsening performance of the final series, due to the greater effort and energy expenditure in the beginning, a fact that was not observed either. Knowledge of the final moment of exercise may induce different responses ${ }^{18}$, since physical effort is unknown, subjects can save more energy and present less performance. However, there was also no difference among the groups for the condition in which the volume was omitted.

According to our knowledge, this was the first experiment to explore the influence of previous information about the number of series on the training volume in leg press $45^{\circ}$ in middle-aged women. Thus, a more consistent comparison with the literature is limited. However, Billaut et al. ${ }^{18}$ verified the effect of anticipating the number of sprints on performance, muscle activation and perception of effort during repeated sprints in 14 women athletes with experience in competition of at least four years. In one session, the participants received the information that would perform 10 six-second sprints (with a 24-second interval) on the cycle ergometer, and, in fact, they concluded them. In another session, they were reported to perform five sprints, but after the fifth, they did five more. In a third condition, the participants were not previously oriented on the quantity of sprints, however, they also performed 10 . The results indicated that the participants, when informed that they would perform only five sprints, were induced to higher performance in the initial sprints compared to the other conditions. However, in the accumulated of the 10 series, there was no difference for the condition in which they were reported over five or 10 sprints; only the situation of lack of knowledge about the volume that was lower. Such finding might be based on the assumption that, even unconsciously, there would be a tendency to save effort in the higher volume condition, thus leading to lower energy expenditure and greater fatigue during the first series.

Therefore, Billaut et al. ${ }^{18}$ reported that the previous information affected performance during repeated sprints, in which the subjects probably saved themselves when they knew they would be submitted to a higher volume. The explanation for the difference of this investigation with ours may be, at least in part, linked to the sample inherent distinctions, since the participants of the study by Billaut $e t$ $a l .{ }^{18}$ were young adults and athletes, while in ours they were middle-aged adults experienced in resistance training, but not athletes. Another important discrepancy among the studies is associated with the different motor tasks used. It is not also possible to ignore, that our research adopted the participants' verbal encouragement to perform maximum repetitions during all series, data not reported by Billaut et al. ${ }^{18}$. The absence of verbal encouragement can result in a greater saving effect, compromising the volume. However, this hypothesis has not been tested in any of these investigations and will need to be confirmed in future studies.

Our results pointed out that it was not possible to maintain performance during the series, with a reduction in performance throughout the series. This information corroborates the results found by Ribeiro et al. ${ }^{22}$, who observed a reduction in performance among the series in women trained in the supine exercise, by performing them until muscle failure at $80 \%$ of 1RM. Eches et al. ${ }^{23,26}$ also found that it was not possible to sustain the number of repetitions throughout the series at $70 \%$ of the maximum force. It is worth noting that the reduction in performance was more accentuated from the first to the second series than for subsequent ones. This result would already be expected, since the first series is the only one in which the individual is in full condition for the effort.

It should be emphasized that the present study has some limitations. The volume of training used can be considered moderate, so a larger volume could induce different results. We also used only one exercise, so different results could be observed in a typical session involving more resistance exercises. It is also worth highlighting that the response may depend on the complexity of exercise and muscle groups involved. In addition, our findings were found in middle-aged women experienced in resistance training, in a way that the analyzes must not be extrapolated to other populations.

On the other hand, according to our knowledge, so far, it was the first experiment to use this approach in resistance exercises. From a practical point of view, the results found in the present study have important implications, because multiple series are commonly used in resistance exercises, due to greater efficiency for increased strength and muscle mass $^{18}$. Therefore, regardless of the training characteristic, with low or high volume, it will not be mandatory to inform the practitioner about how many series will be performed.

\section{Conclusion}

The results found in this investigation suggest that there 
is no effect of prior information of the number of series on the total volume of training in leg press $45^{\circ}$ in middle-aged women previously trained.

\section{References}

1. Cruz-Jentoft AJ, Bahat G, Bauer J, Boirie Y, Bruyere O, Cederholm T, et al. Sarcopenia: revised European consensus on definition and diagnosis. Age Ageing 2019;48(1):16-31. doi: 10.1093/ageing/afz046

2. Clark BC, Manini TM. Functional consequences of sarcopenia and dynapenia in the elderly. Curr Opin Clin Nutr Metab Care 2010;13(3):271-6. doi: 10.1097/MCO.0b013e328337819e

3. Srikanthan P, Karlamangla AS. Muscle mass index as a predictor of longevity in older adults. Am J Med 2014;127(6):547-53. doi: 10.1016/j.amjmed.2014.02.007

4. Ruiz JR, Sui X, Lobelo F, Morrow JR, Jr., Jackson AW, Sjostrom M, et al. Association between muscular strength and mortality in men: prospective cohort study. BMJ 2008;337:a439. doi: 10.1136/bmj.a439

5. Janssen I, Heymsfield SB, Wang ZM, Ross R. Skeletal muscle mass and distribution in 468 men and women aged 18-88 yr. J Appl Physiol (1985) 2000;89(1):81-8.

6. Delmonico MJ, Harris TB, Visser M, Park SW, Conroy MB, Velasquez-Mieyer $\mathrm{P}$, et al. Longitudinal study of muscle strength, quality, and adipose tissue infiltration. Am J Clin Nutr 2009;90(6):1579-85. doi: 10.3945/ajcn.2009.28047

7. Garber CE, Blissmer B, Deschenes MR, Franklin BA, Lamonte MJ, Lee IM, et al. American College of Sports Medicine position stand. Quantity and quality of exercise for developing and maintaining cardiorespiratory, musculoskeletal, and neuromotor fitness in apparently healthy adults: guidance for prescribing exercise. Med Sci Sports Exerc 2011;43(7):133459. doi: 10.1249/MSS.0b013e318213fefb

8. Fragala MS, Cadore EL, Dorgo S, Izquierdo M, Kraemer WJ, Peterson MD, et al. Resistance training for older adults: Position statement from the National Strength and Conditioning Association. J Strength Cond Res 2019;33(8):2019-52. doi: 10.1519/JSC.0000000000003230

9. Cadore EL, Rodriguez-Manas L, Sinclair A, Izquierdo M. Effects of different exercise interventions on risk of falls, gait ability, and balance in physically frail older adults: a systematic review. Rejuvenation Res 2013;16(2):105-14. doi: 10.1089/rej.2012.1397

10. Latham NK, Bennett DA, Stretton CM, Anderson CS. Systematic review of progressive resistance strength training in older adults. J Gerontol A Biol Sci Med Sci 2004;59(1):4861.

11. Lopez P, Pinto RS, Radaelli R, Rech A, Grazioli R, Izquierdo $\mathrm{M}$, et al. Benefits of resistance training in physically frail elderly: a systematic review. Aging Clin Exp Res 2017. doi: $10.1007 / \mathrm{s} 40520-017-0863-\mathrm{Z}$
12. Cadore EL, Pinto RS, Bottaro M, Izquierdo M. Strength and endurance training prescription in healthy and frail elderly. Aging Dis 2014;5(3):183-95. doi: 10.14336/ AD.2014.0500183

13. ACSM. American College of Sports Medicine position stand. Progression models in resistance training for healthy adults. Med Sci Sports Exerc 2009;41(3):687-708. doi: 10.1249/ MSS.0b013e3181915670

14. Schoenfeld BJ, Contreras B, Krieger J, Grgic J, Delcastillo $\mathrm{K}$, Belliard $\mathrm{R}$, et al. Resistance training volume enhances muscle hypertrophy but not strength in trained men. Med Sci Sports Exerc 2019;51(1):94-103. doi: 10.1249/ MSS.0000000000001764

15. Schoenfeld BJ, Ogborn D, Krieger JW. Dose-response relationship between weekly resistance training volume and increases in muscle mass: A systematic review and meta-analysis. J Sports Sci 2017;35(11):1073-82. doi: 10.1080/02640414.2016.1210197

16. Ralston GW, Kilgore L, Wyatt FB, Baker JS. The effect of weekly set volume on strength gain: a meta-analysis. Sports Med 2017;47(12):2585-601. doi: 10.1007/s40279-017-07627

17. Moran-Navarro R, Perez CE, Mora-Rodriguez R, de la CruzSanchez E, Gonzalez-Badillo JJ, Sanchez-Medina L, et al. Time course of recovery following resistance training leading or not to failure. Eur J Appl Physiol 2017;117(12):2387-99. doi: 10.1007/s00421-017-3725-7

18. Billaut F, Bishop DJ, Schaerz S, Noakes TD. Influence of knowledge of sprint number on pacing during repeated-sprint exercise. Med Sci Sports Exerc 2011;43(4):665-72. doi: 10.1249/MSS.0b013e3181f6ee3b

19. Amarante do Nascimento M, Borges Januario RS, Gerage AM, Mayhew JL, Cheche Pina FL, Cyrino ES. Familiarization and reliability of one repetition maximum strength testing in older women. J Strength Cond Res 2013;27(6):1636-42. doi: 10.1519/JSC.0b013e3182717318

20. Rossi FE, Schoenfeld BJ, Ocetnik S, Young J, Vigotsky A, Contreras B, et al. Strength, body composition, and functional outcomes in the squat versus leg press exercises. J Sports Med Phys Fitness 2018;58(3):263-70. doi: 10.23736/S00224707.16.06698-6

21. Ribeiro AS, Afonso C. Selection-related aspects of resistance exercises for elderly. J Health Sci 2019;21(3):208-15. doi: 10.17921/2447-8938.2019v21n3p208-215

22. Ribeiro AS, Avelar A, Schoenfeld BJ, Trindade MC, RittiDias RM, Altimari LR, et al. Effect of 16 weeks of resistance training on fatigue resistance in men and women. J Hum Kinet 2014;42:165-74. doi: 10.2478/hukin-2014-0071

23. Eches EHP, Ribeiro AS, Nascimento MA, Cyrino ES. Motor performance in sustained multiple weight exercises to concentric failure. Motriz 2013;19(3):S43-S8. 